\title{
History of Church Design in Olszyna Lubańska
}

\author{
Aleksandra Repelewicz ${ }^{1}$ and Zbigniew Madurowicz ${ }^{2}$ \\ 1. Department of Civil Engineering, Czestochowa Technical University, Częstochowa 42-200, Poland \\ 2. Association of Upper Lausitz Enthusiasts, Lubań 59-800, Poland
}

\begin{abstract}
The history of the design of St. Joseph the Betrothed church in Olszyna Lubańska is presented in the paper. The first design of the church was drawn up by a local master builder in 1889 but was given such a poor evaluation by a firm of architects in Berlin that a new project had to be commissioned. The technical opinion on the design is analysed in the paper: both projects are discussed and some of the drawings from the projects are presented. The text of the expert evaluation and the draft of the church have never been published yet.
\end{abstract}

Key words: Sacral architecture, church design evaluation, parish church, Olszyna Lubańska.

\section{Introduction}

Olszyna Lubańska (Langenòis) is situated in the province of Dolny Śląsk, right on the border with Łużyce Górne, in the county of Lubań. Historically, the town belongs to Dolny Śląsk. Geographically, it is located in the Izerskie Foothills, on the river Olszówka, which is a tributary of Kwisa.

The history of this border town has been extremely turbulent. Olszyna Lubańska is first mentioned in the 13 th century. Initially, the town was ruled by the kings of Bohemia and then by the Margrave of Brandenburg. In the 14th century, Olszyna Lubańska became part of Bohemia once again and later part of Hungary (1469-1490). In 1490, it came under the dominion of the Jagiellonian dynasty and then of the Habsburgs (1526-1635). After the peace settlement in Prague, the citizens of Olszyna Lubańska became the subjects of the Saxon kurfirsts for the next 180 years. After that, the Congress of Vienna gave Olszyna Lubańska to the King of Prussia. It remained in this dominion until the reunification of Germany in 1871. The town belonged to Germany until 1945, when the area was ceded to Poland. In 2005, Olszyna Lubańska was granted city rights $[1,2]$.

Corresponding author: Aleksandra Repelewicz, Ph.D., research field: sacral architecture.

\section{The History of the Church Project in Olszyna Lubańska}

The population of Olszyna greatly increased in the second half of the 19th century. Rapid industrial development led to increased personal wealth and, consequently, a desire from the protestant community to build a new church. The man behind the idea was the new pastor, Ernst Wieder, formerly a deacon in Hoyerswerda. The original protestant prayer house, which had been erected during the reign of Frederick the Great, was in poor structural condition after numerous floods and on the point of collapse. The great flood of 1888 seriously damaged the prayer house, which was a transom structure. This calamity hastened the construction of a new church. The Board of the Church (Runge, Glaubitz, Hoffmann and Lauer), together with the pastor, asked the district master builder Müller from Züllichau (Sulechów) to draw up plans for a new church. The specification for the project was formulated and is contained in a hand-written document by the government construction engineer-Von Zsock, dated back to November 1st, 1889. This document, unfortunately, has not survived to this day. A reference to it, however, can be found in the technical evaluation of the project. The project was completed and sent to Langenöis 
(Olszyna Lubańska) [3].

The church was designed in a neo-Gothic style, on a rectangular plan, with one-storey, a gable roof and a slender tower (Fig. 1).

For unknown reasons, the Board of the Church decided to seek an expert evaluation of the draft and commissioned a Berlin project office to carry it out. The letter, which accompanied the drawings (dated at January 1st, 1891), is a technical evaluation of the new evangelical church project (Fig. 2) [4].

The text of the expert evaluation and the draft of the church have never been published and come from private collections. They were found some years ago among private papers.

\section{Expert Evaluation Concerning the First Design of the Church}

The expert evaluation of the project was largely negative. It recommended installing 1,000 seats in the new church. Although the original project of the church included the recommended number of seats (710 in the nave and 328 in galleries), the experts drew attention to the fact that rows of pews had been extended so far in the direction of presbytery that they surrounded the pulpit. What is more, the central aisle had insufficient width and the stalls partially blocked the eastern entrance. A sketch of the church shows that the distance between the pews in the middle of the nave was designed to be just $1.5 \mathrm{~m}$. This forms an exceptionally narrow passage, not practical fora processional crossing of the middle of the church.

A further paragraph from the expert evaluation focuses on the spatial arrangement of the presbytery. In the experts' opinion, it was surrounded by an inappropriate "special cloister". The presbytery traditionally served as a location for a patronage gallery, which, in fact, could not have been situated there because of the dimensions of the cloister.

A further criticism of the original design was the too low cost of construction. The cost of a "utility unit" (one seat) was 93 German marks. Among contemporary

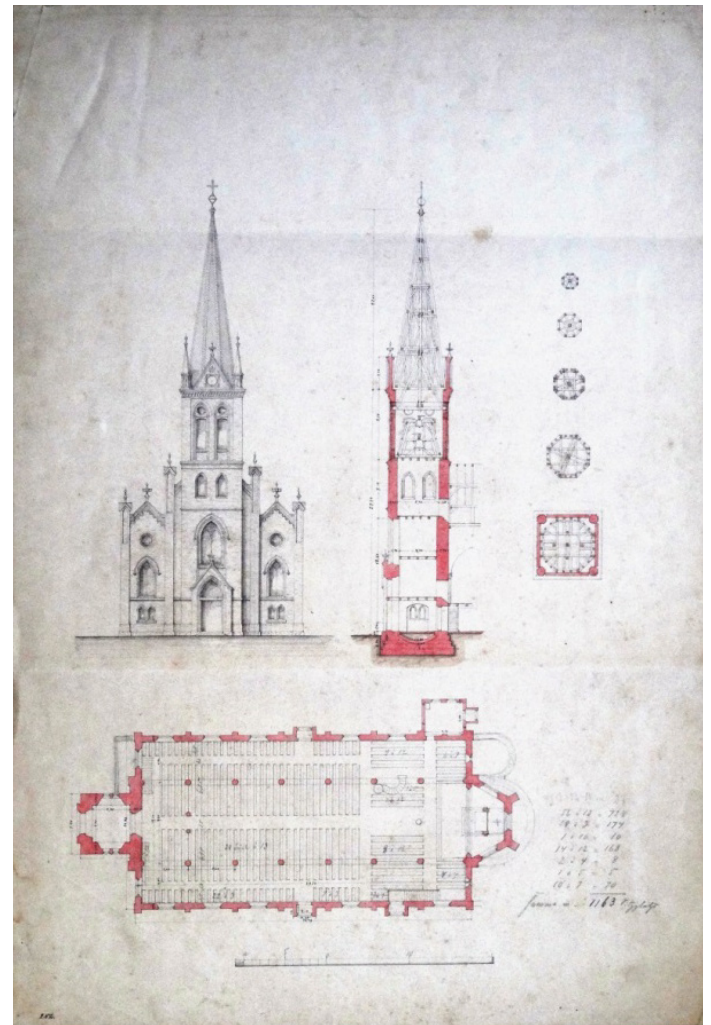

Fig. 1 The first page of the initial project of the church, drawn up by master builder Müller in $\mathbf{1 8 9 0}$.

Source: a private collection.

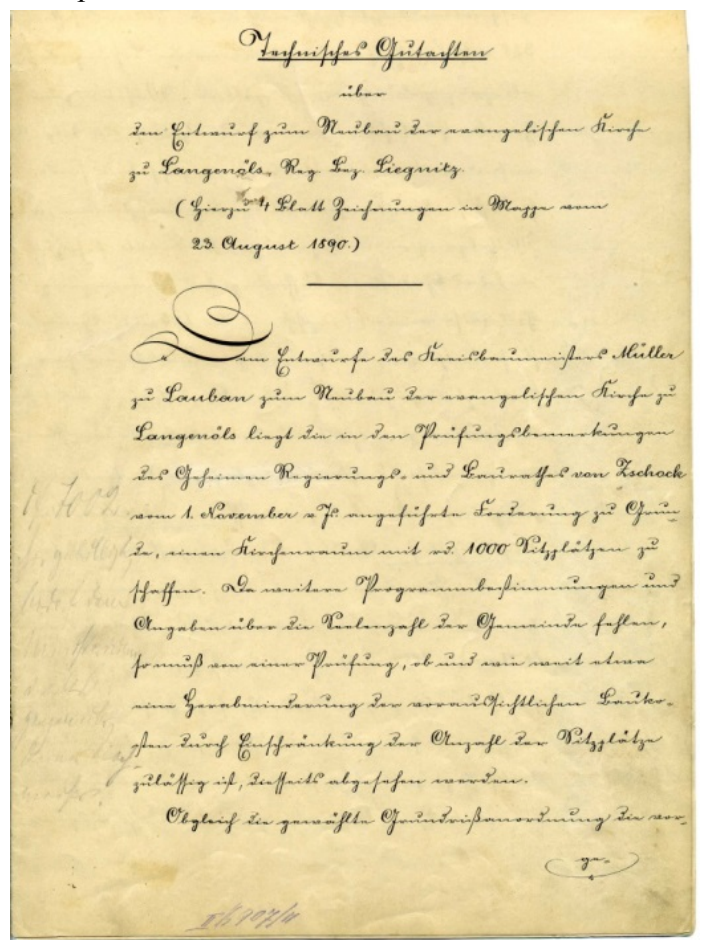

Fig. 2 The first page of the technical evaluation of the Evangelical Church project in Olszyna.

Source: a private collection. 
churches of a similar size, with a tower and a vaulted ceiling, this figure typically varied between 120 140 marks. It is highly probable, in this period, that information about the average cost of constructing comparable objects (with similar cubic capacity and functions) was widely known. Low construction costs were considered to be a disadvantage. It was pointed out that higher costs help to ensure the erection of a more solid, safer building. It seems likely that lower utility unit cost in the original project was achieved by tight spacing of the pews. This enabled a relatively large number of seats to be packed into a small area. Nowadays, it is hard to identify the exact reasons for such a significant difference between the estimated and recommended costs of the object.

The expert evaluation deemed that locating an outhouse on the north side of the tower was not only unnecessary but highly inappropriate. It is not clear whether this refers to the specific location of the toilet, or more generally to the placing of such facilities within a house of worship. It should be noted that the second version of the project did not include toilet facilities. This may suggest that such facilities were not seen as required within churches in those days.

In addition, the experts-Zinden and Adler-were critical of the size and height of the proposed windows. They concluded that the windows could be lower and narrower without any loss of light inside the church. The experts went on to reprove the designer for disregarding the Prussian fire regulation from August 18th, 1884, which concerned, in particular, the rules for locating the stairs and fire exits.

The most important objection in the expert evaluation concerning construction, was that the drawings did not provide enough information about the safety of the structure of the church. In particular, the support arches with $10 \mathrm{~m}$ spans. It was pointed that the dimensions of the pillars intersecting the two naves were not clear enough to be read.

Furthermore, it was stated that the binding of the roof shown in the drawings was not realizable. The brevity of this claim means it is difficult to say whether the opinion is based on the use of too small sections of wooden truss elements or rather the overall excessive complexity of the design of the roof. The original design of the tower was extremely complicated and each node was connected to a large number of horizontal, vertical and diagonal wooden elements. The carpentry would have been extremely sophisticated and the necessary wooden joints would have dangerously reduced the cross-sectional elements.

The fact is that the new sketch of the tower roof significantly simplified the construction and shows just half the number of components were needed to erect the roof. It should be noted that the height of the tower was not changed significantly. The original project planned a 22-metre high tower roof structure and the new draft-21.3 m.

The final paragraphs of technical evaluation on the original design recommended simplifying the plan of the church, in particular, decreasing the built-up area and significantly reducing the height of the nave walls and vault span, in order to reduce the total cost of construction.

In conclusion, the technical evaluation judged the project to be inadequate. Zinden and Adler decided it could serve only as a basis for a further draft. They concluded that it was not enough just to correct the original sketches but that a completely new project should be commissioned.

\section{The New Project of the Church}

The negative opinion given by the experts on the original draft of the church led to a new one being commissioned. The new project was drawn up in 1891, and the church which was built on the basis of it still stands today. The builder of this new edifice was foreman Schlippmann.

Today, drawings of the church can be seen in the State Archives in the nearby town of Luban Ślaski. The first page of the project was signed by the Royal County Building Inspector, who probably was not 


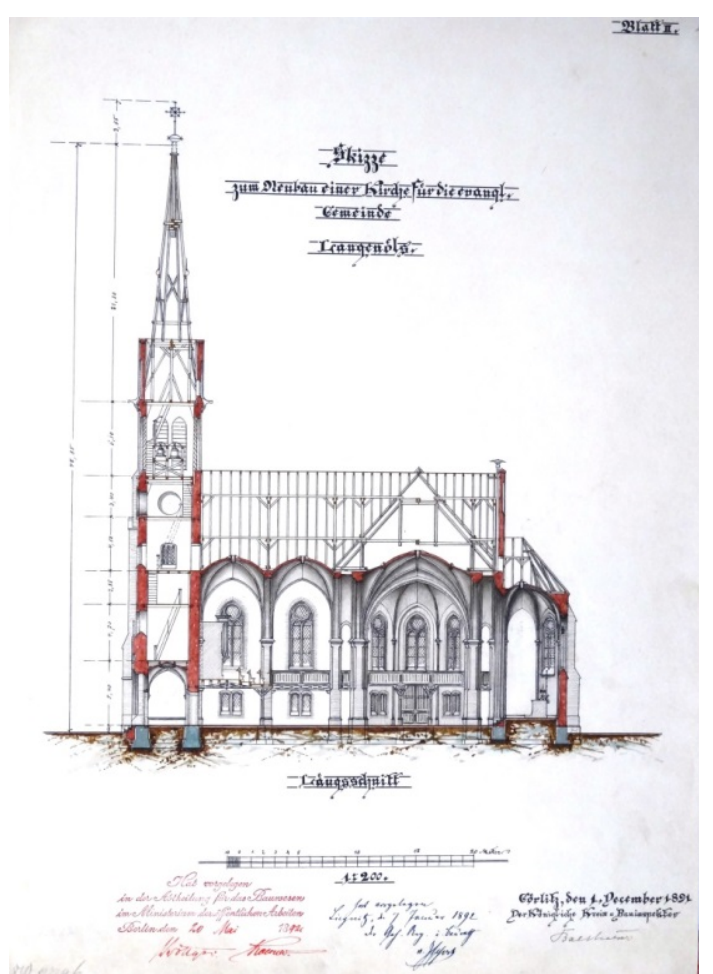

Fig. 3 The section of the church building (the second version of the project).

Source: the collection of the state archive in Lubań Ślaski.

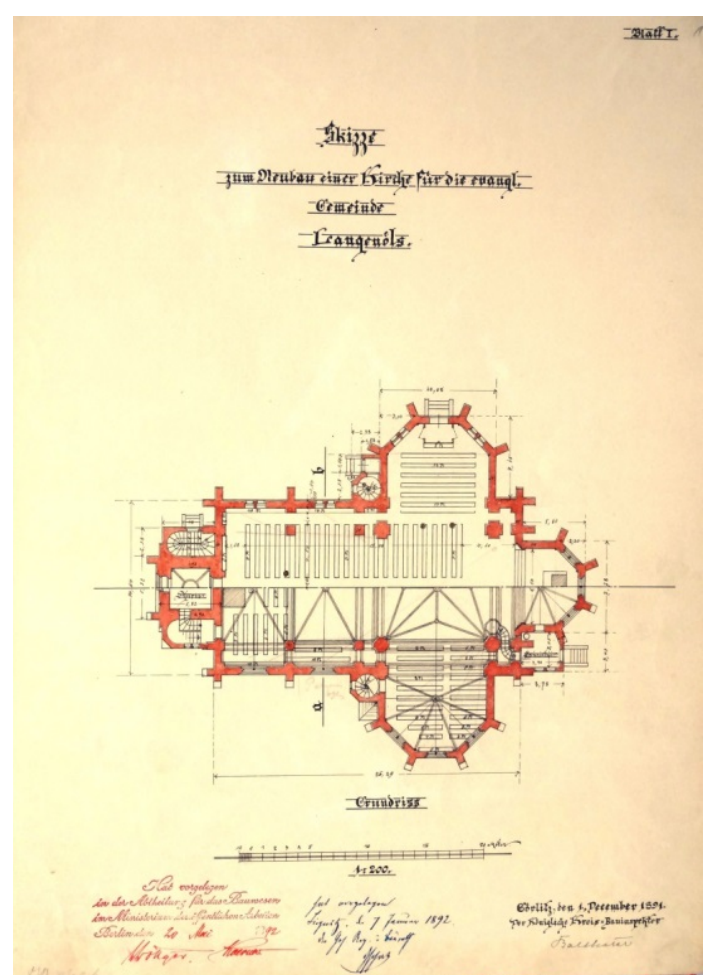

Fig. 4 A ground floor level of the church building (the second version of the project).

Source: the collection of the state archive in Lubań Ślaski. strictly its author, but the one who approved the final version of the project. His signature is the oldest and dates from 1891. Other signatures on the drawing date from 1892 [5].

In line with the recommendations contained in the technical opinion, the new object was smaller than the one originally planned. The nave, which in the first version had dimensions of $19.60 \mathrm{~m} \times 39.20 \mathrm{~m}$, was reduced to $12.60 \mathrm{~m} \times 24.76 \mathrm{~m}$. The ground floor area was originally planned to be almost $800 \mathrm{~m}^{2}$, but in the realized object is less than $400 \mathrm{~m}^{2}$ in area. Some of the pews were installed in the galleries, situated along the side walls and above the entrance. This was a very practical solution which maximized usable space, without increasing the dimensions and volume of the building (Figs. 3 and 4).

Toilet facilities were not placed inside the building, as mentioned above. The construction of the tower was significantly simplified but leaving the tower roof practically the same height, and maintaining its original shape.

It should be mentioned that the total cost of erecting the church built on the basis of the new project was a more financially sound investment.

The building was designed in a neo-Gothic style (Figs. 5 and 6), on a cruciform plan, with an indoor shape of hall and vaulted annexes that imitate lateral naves (Fig. 7).

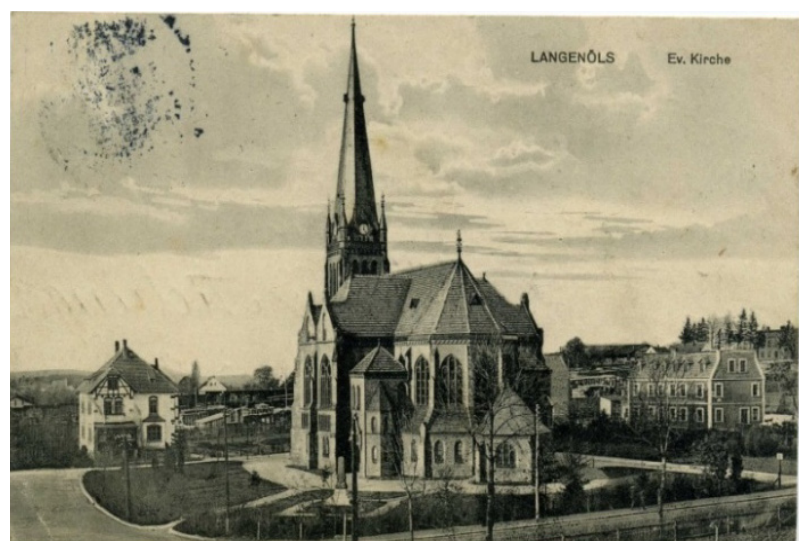

Fig. 5 The church in Olszyna Lubańska from an old postcard.

Source: Z. Madurowicz collections. 


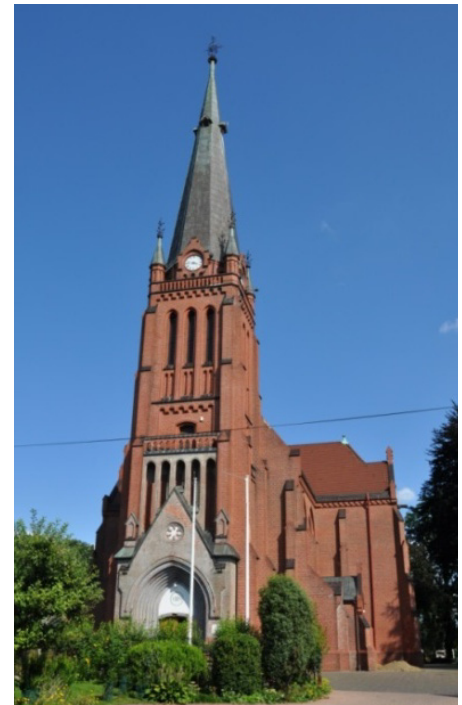

Fig. 6 Contemporary view of the church in Olszyna Lubańska.

Source: photo by A. Repelewicz.

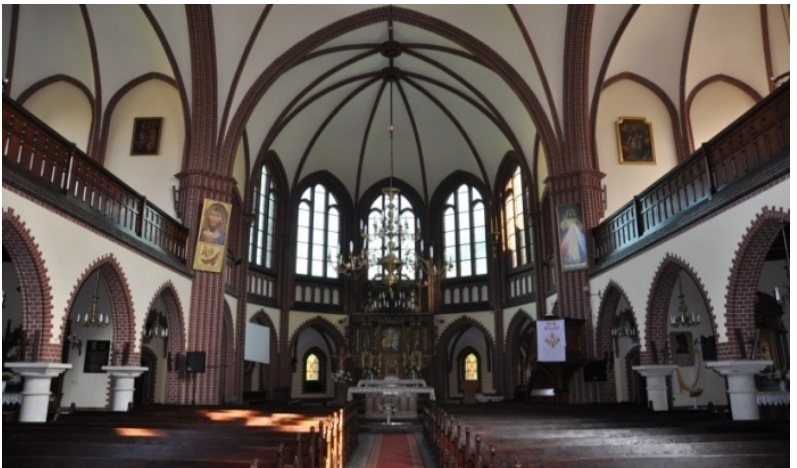

Fig. 7 Interior of the church in Olszyna Lubańska.

Source: photo by A. Repelewicz.
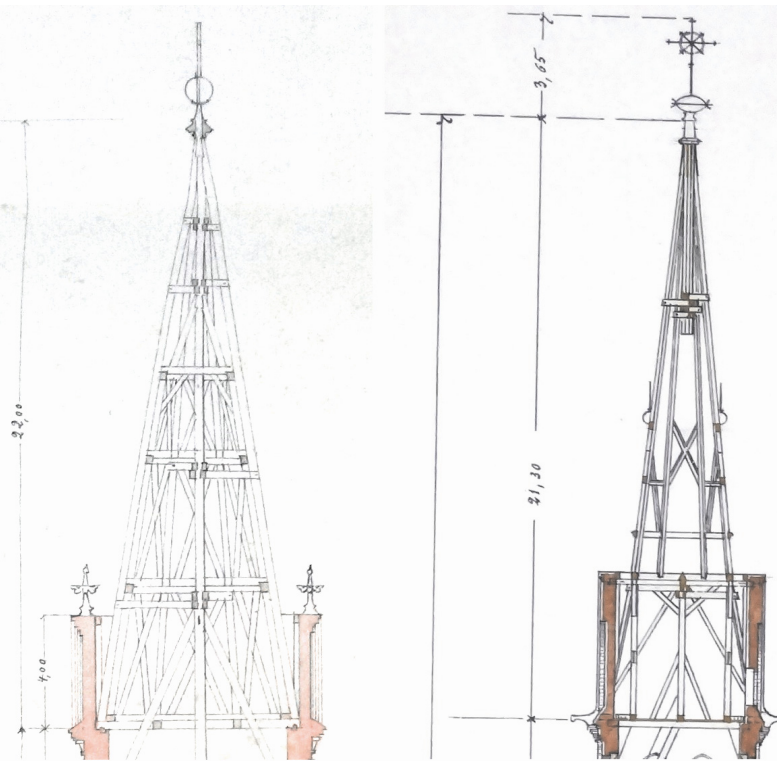

Fig. 8 Comparison of the tower structure in both projects.

Source: the first and the second versions. 


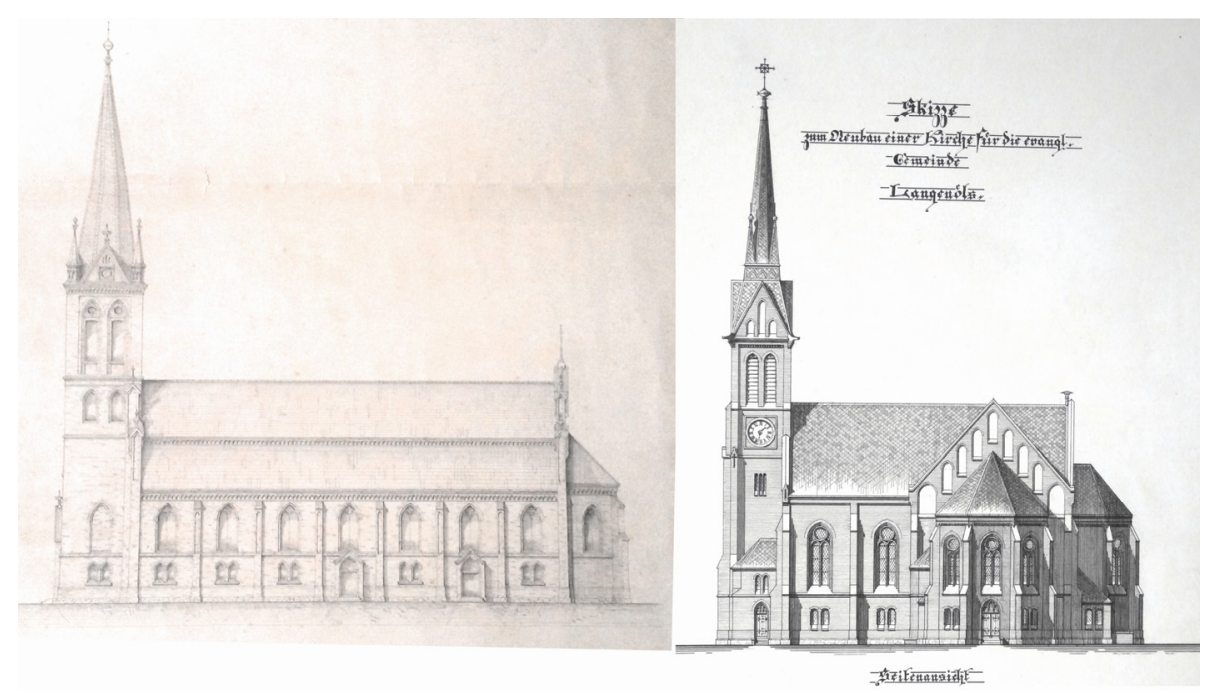

Fig. 9 Comparison of the elevations in both projects.

Source: the first and the second versions.

The church was originally built as a Protestant parish church, but has ever since become a Roman Catholic one.

\section{Conclusions}

After more than a hundred years, it has proved possible to trace the origins of the church of St. Joseph the Betrothed in Olszyna Lubańska. Analysis of the technical evaluation, which resulted in the rejection of the first church drawings and the necessity of drawing up new ones, proves that most of the criticisms were fully justified. Even though, by modern standards, it is difficult to accept that the church could have been built without toilet facilities. Comparing the two projects, it is patently clear that the decision to review the original draft was sagacious as the second project has several notable advantages over the first (Figs. 8 and 9). Most appreciable among them is the more imposing interior and exterior of the building.

\section{References}

[1] Madurowicz, Z. 2004. Olszyna w Historię Wpisana, w tym Biedrzychowice i Okolice (Olszyna Entered in History, Including Biedrzychowice and Its Surroundings). Olszynie: Urząd Gminy w Olszynie (Municipal Office in Olszyna). (in Polish)

[2] Maroń, J., and Tekiela, Ł. 2007. Górne Łużyce na Przestrzeni Wieków (Upper Lusatiaover the Centuries). Lubań: Stowarzyszenie Miłośników Górnych Łużyc (Associacion of Upper Lausitz Enthusiasts). (in Polish)

[3] Master Builder Müller. 1890. The design of the church in Langenòis (First Version). (unpublished)

[4] Berlin. 1890. The Technical Evaluation of the Project Evangelical Church in Olsztyna, Region of Legnica. Berlin. (unpublished)

[5] Gòrlitz. 1891. The Design of the Church in Langenòis (Second Version). Görlitz. (unpublished) 